therefore, to offer a simple definition: A hospital hostel is a unit for the chronically mentally ill in which:

(1) the residents remain in-patients;

(2) the building is physically separate from the parent hospital;

(3) the daily programme places an emphasis on the performance of 'life skills' such as cooking, shopping and cleaning.

If criterion (2) is not met I suggest that the unit is a hostel ward, whereas if only (1) and (2) apply the facility is a ward in the community. Hospitals hostels, then, have been operating in the United Kingdom for over 25 years, but surprisingly no-one seems to know how many there are. It is my impression, however, that there are many more quasi hospital hostels in which the residents are discharged patients contributing their DHSS benefits to the funding of the hostel. In Oxford, for example, although we have only two hospital hostels, there are five hostels for the chronically mentally ill, heavily supported by Health Authority staff, run by the independent charity Oxford Group Homes Organization.

Although there may be some advantages in separating hostels from the more regressive aspects of hospital care, I believe the main motive for the development of 'quasi hospital hostels' has been financial. The demand-led nature of DHSS benefit-payments has in recent years permitted developments impossible for cash-limited and 'RAWped' Mental Health Units. Around Britain much time and ingenuity have been expended in setting up such hostels, but as the Audit Commission pointed out, the resultant complex arrangements are not necessarily the most costeffective way of spending taxpayers' money.

Within Sir Roy Griffiths' Report, however, there is a suggestion which if followed would resolve many absurdities, whilst ensuring the quality of care currently being delivered by hospital hostels. Paragraph 6.12 states "The responsibilities of regional and district health authorities should in general continue to be the provision of health care. In broad terms this involves investigation, diagnosis, treatment and rehabilitation undertaken by a doctor or by other professional staff to whom a doctor... has referred the patient." This means to me that the "severely disabled psychiatric patient", "new long stay", or "young adult chronically mentally ill" should be recognised as requiring health care and treatment whilst living in their "ward", "hospital ward", "hospital hostel" or "staffed hostel", and that it is a Health Authority duty to provide the resources. If this recommendation was accepted one could then be confident that the best setting for any individual patient would be determined, as it should be, by clinical factors alone.

Littlemore Hospital,

G. L. Pullen

\section{Video of treatments in psychiatry}

\section{DeAR Sirs}

I am endeavouring to produce a video for the use of paramedical staff in hospitals and the community to show commonly used treatments in psychiatry. This will include physical treatments, e.g. ECT, and psychological treatments, e.g. biofeedback, reality orientation. Subsequent editions may be planned for medical students and junior doctors new to psychiatry.

May I through the Bulletin enquire whether similar audio visual presentations have been made. Any help and information will be greatly appreciated.

The Oaks,

N. A. Suleman

31 Slades Farm Road,

Bournemouth BH10 4EV

\section{Alternatives to the mental hospital patient}

DeAR SIRS

The May issue of the Bulletin reflects the growing concern and anxiety of many psychiatrists with their own (and in some instances with their patients') future.

Alternatives to the mental hospital are urgently canvassed and just as anxiously called into question.

I have a suggestion. Instead of thinking about alternatives to the mental hospital perhaps we should be thinking in terms of alternatives to the mental hospital patient.

It is a matter of horses for courses. Some psychiatrists are more adept at looking after certain sorts of patients than other patients with dissimilar troubles. For example, some would prefer young, educated, and articulate customers: and in this context it has often struck me that one suitably favoured patient could last a similarly endowed psychiatrist both their respective lives - this being more likely in the non-organic fields of psychiatry.

But how, I hear you ask, Mr Editors, can all this be brought about? Well, having regard to the prevailing political ideology of market forces it might be perfectly feasible (and I propose to patent this idea, so don't let anyone try and jump in on the act) to set up a Central Agency which would endeavour to match particular patients to particular psychiatrists (the idea has, of course, worked quite well in other areas of human endeavour).

Interested parties could then apply to the Central Agency, stating their preferences. One anticipates that there would be a greater demand from some psychiatrists for upwardly mobile psychotherapeutically inclined executives with the burn-out syndrome than for, say, more chronic forms of dementia. 
But - and this again is what I take to be current Government health policy along the lines of Health Authorities buying in services - there would be an ingenious differential payment for different categories. Without going into tedious cost benefit analysis, in broad principle the more preferred patients would cost the psychiatrist more-and the profit from this would be used to compensate the psychiatrist taking the less preferred patient, longstay or whatever, a sort of merit award.

The operation, I must stress, would of course be entirely non profit making as far as the Central Agency would be concerned - setting aside a small sum for administrative expenses and the unit managers of the Agency.

The idea, I admit has its deficiences. It is unfortunate that it does not cater for the needs of those psychiatrists who are drawn towards committee work and consensus management: but they could always become elected or co-opted members of the Agency. Think about it.

Old Rectory House

Chapter House Street, York

ARTHUR Bowen

\section{Mental Health Review Tribunals}

DeAr Sirs

I have become increasingly embarrassed and saddened, as a member of the South Western Mental Health Review Tribunal, at the somewhat cavalier attitude of some of our psychiatric colleagues towards attendance at, in particular, Section 2 hearings which, of necessity, have to be arranged at short notice. This presents a major logistical exercise for a tiny, but very conscientious, Tribunal office staff, in finding legal, medical and lay members all available at the same time and the same day, often after a journey of many miles. Having done this, I feel it is neither courteous nor helpful for the RMO to refuse to attend at the appointed time because he has a previous out-patient appointment or to complain if there is any unforeseen delay in proceeding on the day of the hearing.

I believe that the majority of Tribunal members, legal, lay and medical, may well share the widespread doubts of many colleagues about the justification for Section 2 appeals, but, the fact is that the 1983 Act still requires them, and that however inconvenient they are a burden we all have to share.

Although Tribunals are usually conducted in a relatively informal manner, they remain a statutory, legal forum, which deserves, I suggest, the respect of at least a tie, if not a jacket, from medical (and other staff?) appearing before it.

Flat 2, 38 Apsley Road

W. Alan Heaton-Ward Clifton, Bristol BS8 2SS

\section{Royal Prerogative?}

DeAr Sirs

I am a consultant psychiatrist working in mental handicap. As part of the assessment of the degree of handicap of the patients that I am asked to see, I administer a short test. One of the questions involved concerns the sex and name of the monarch.

Of the last five patients to whom I have given this questionnaire, four accurately stated that there was a queen on the throne. However, three of these were confused about the identity of the person, confidently stating that her name was Mrs Thatcher. Sic transit gloria reginae.

Prudhoe Hospital

STEPHEN P. TYRER 